\title{
Complementary approaches demonstrate that cellular aromatization in the bank vole testis is related to photoperiod
}

\author{
M. Kotula-Balak, ${ }^{*}$ M. Slomczynska, ${ }^{*}$ B. Fraczek, ${ }^{*}$ S. Bourguiba," Z. Tabarowski, ${ }^{\circ}$ S. Carreau," \\ B. Bilinska* \\ * Laboratory of Endocrinology and Tissue Culture, ${ }^{\circ}$ Laboratory of Experimental Hematology, Department \\ of Animal Physiology, Institute of Zoology, Jagiellonian University, Kraków, Poland; "3EA 2608-USC INRA, \\ Biochimie-IRBA, University of Caen, Caen, France
}

\section{(C)2003, European Journal of Histochemistry}

A growing body of evidence indicates that germ cells, at least in several mammalian species, are responsible for estrogen formation since they possess active aromatase. In seasonally breeding rodent, the bank vole, the length of photoperiod seems to be the primary environmental factor regulating annual changes in the reproductive activity. However, in this species gonadal steroidogenesis is still not well understood, neither the site of aromatization in testicular cells.

In the bank vole testis, aromatase visualized by immunohistochemistry was found in Leydig cells, Sertoli cells, and germ cells: especially in spermatocytes and spermatids. Moreover, in the immuno-electron microscopic study, gold particles indicating aromatase were observed over the cytoplasm of elongated spermatids. The presence of aromatase and the activity of this enzyme were found in microsomal preparations of the whole testes and those of seminiferous tubules. This was measured by means of Western blot and the biochemical assay with tritiated androstenedione, respectively. Additionally, using radioimmunological assays testosterone and estradiol concentrations in homogenates were detected. All the studied parameters revealed close correlation with the length of photoperiod being evidently higher in animals kept in the long day conditions when compared with those from short light cycles.

Key words: aromatase, P450 aromatase activity, immunohistochemistry, testosterone, estradiol, testis, bank vole.

Correspondence: Prof. Dr. Barbara Bilinska, Institute of Zoology, Jagiellonian University, Ingardena 6, 30-060 Krakow, Poland. Fax: +48.126340785.

E-mail: bbili@zuk.iz.uj.edu.pl

Paper accepted on November 8, 2002

\section{European Journal of Histochemistry}

2003; vol. 47 issue 1 [Jan-Mar]:55-62
I n seasonal breeders, terminal differentiation of the gonads can be retarded or even stopped by changes in the photoperiod. Therefore its length is one of the most important factors inducing changes in the reproductive activity. Moreover, the reproductive cycle of seasonally breeding rodents, such as the bank vole can be easily mimicked under laboratory conditions by subjecting the animals to different light cycle regimes (Tähkä et al. 1982; Bilinska et al. 1999).

Aromatase (P450arom) is a member of the P450 cytochrome family encoded by cyp19 gene. This enzyme also known as estrogen synthase (EC 1.14.14.1) catalyses the transformation of androgens into estrogens (Simpson et al. 1994; Conley and Hinshelwood 2001).

During the last decade, a series of studies described the activity of aromatase and its distribution at a cellular level of the mammalian testis (for review, see Carreau et al. 1999). Interestingly, age-related changes in aromatase expression have been observed in the rat: in adult males, the principal source of estrogens are Leydig cells, whereas in young ones Sertoli cells have been implicated in estrogens' production (Papadopoulos et al. 1986). Several studies have also shown the presence of P450 aromatase in testicular germ cells of various animals: brown bear (Tsubota et al. 1993), rooster (Kwon et al. 1995), mouse (Nitta et al. 1993; Janulis et al. 1996), and rat (Janulis et al. 1998; Levallet et al. 1998a,) what was not the case in equine, porcine, and ovine testes (Almahdidi et al. 1995; Conley et al. 1996; Bilinska et al. 1997). In those species aromatase was localized only in Leydig cells. In humans, immunoreactive aromatase has been shown in ovaries, testes, prostate, brain, and cancer tissues (Noble et al. 1993; Jakob et al. 1995; Santner et al. 1997; Brodie et al. 2001).

In order to improve our understanding of the testicular site of aromatization in the bank vole, four complementary methods have been used to demon- 
strate the testicular sources of estrogens. These included studies on: (1) aromatase immunoexpression at the light and electron microscope levels, (2) the presence of aromatase (3) its enzymatic activity, and (4) the levels of steroid hormones in testicular homogenates. All experiments were performed on animals that were kept either in long or short light cycles.

\section{Materials and Methods Animals}

Sexually mature bank voles (Clethrionomys glareolus, Schreber) deriving from our own colony (Laboratory of Animal Endocrinology and Tissue Culture, Institute of Zoology, Jagiellonian University) were used. To induce or inhibit sexual maturation of the gonads, animals were reared for 2 months under short light cycles (6L:18D) or long light cycles (18L: 6D).

\section{Ethics of experimentation}

Experiments were performed in accordance with the Polish legal requirements, under the licence given by the National Commission of Bioethics at the Jagiellonian University.

\section{Immunohistochemistry}

Immunohistochemistry was performed on deparaffinized and rehydrated $6 \mu \mathrm{m}$ paraplast sections. Endogenous peroxidase activity was blocked with $3 \% \mathrm{H}_{2} \mathrm{O}_{2}$ in methanol. Sections were then incubated with $5 \%$ normal goat serum to prevent nonspecific staining. After that, they were processed for visualization of aromatase using the immunohistochemical technique described elsewhere (Bilinska et al. 1997, 2001). In short, sections were incubated overnight at $4^{\circ} \mathrm{C}$ in a humidified chamber in the presence of the primary polyclonal antibody against human placental P450 aromatase (1:400; R-10-2; a generous gift from Dr Yoshio Osawa, Hauptman-Woodward Medical Research Institute, Buffalo, NY, USA). This antibody raised in a rabbit was generated against human placental P450arom that had been previously purified by immunoaffinity (Yosida and Osawa, 1991). It was developed with the support of U.S. Public Health Service Research Grant \#HD P4945 from NICHHD. Next, biotinylated secondary antibody, goat anti-rabbit IgG (1:400; Vector Lab., Burlingame, CA, USA) was applied, and then avidinbiotinylated horseradish peroxidase complex (ABC/HRP; 1:100; DAKO A/S, Glostrup, Denmark) was used. The colour reaction was developed in TBS buffer, pH 7.4 containing $0.01 \% \quad \mathrm{H}_{2} \mathrm{O}_{2}, 0.05 \%$ diaminobenzidine, and $0.07 \%$ imidazole (Sigma Chemical Co. St Louis, MO, USA). Finally, counterstaining with Mayer haematoxylin was performed. Controls were incubated with normal rabbit serum instead of the primary antibody. The sections were examined with a Leica microscope (Germany) using a bright field illumination and Nomarski interference contrast.

\section{Immuno-electron microscopic localization of aro- matase}

For EM localization of aromatase, Lowicryl embedding method (Polysciences Inc., Warrington, PA, USA) for immunogold labeling was used. The embedding process was performed in two stages fixation and start of dehydration followed by the completion of dehydration and embedding (according to the manufacturer's instructions). In short, the tissue was fixed in $2 \%$ paraformaldehyde in PBS for $30 \mathrm{~min}$. This is sufficient to preserve the structure reasonably well while still achieving good antigenicity. Then the tissue was dehydrated in 30\% ethanol cooled to $4^{\circ} \mathrm{C}$ (for $30 \mathrm{~min}$ ), and in $50 \%$ ethanol cooled to $-20^{\circ} \mathrm{C}$ (for further $30 \mathrm{~min}$ ), and finally the tissue was transferred to $70 \%$ ethanol at $-20^{\circ} \mathrm{C}$ and left overnight. Then, the tissue was dehydrated in $100 \%$ ethanol and embedded in Lowicryl K4M resin, overnight at $-30^{\circ} \mathrm{C}$, in small gelatin capsules, which were partially immersed in a chamber with $70 \%$ ethanol, and irradiated with ultra-violet light (Philips LTD 15W; Philips, Eindhoven, the Netherlands) for 16 hrs. Next, the chamber was allowed to warm up to room temperature. After consecutive exposition to UV light for $72 \mathrm{~h}$ the complete polymerization of the resin was obtained. Ultrathin sections of the material embedded in Lowicryl were collected on formwar coated nickel grids and incubated with the primary antibody against aromatase (as above), while the secondary antibody was goat anti-rabbit IgG conjugated with $9 \mathrm{~nm}$ colloidal gold (Sigma Chemical Co, St Louis, IL, USA). The sections were examined in a JEM-100SX electron microscope (JEOL, Tokyo, Japan) at $80 \mathrm{kV}$.

\section{Preparation of microsomes}

All steps of microsome isolation have been conducted at $4^{\circ} \mathrm{C}$ in order to preserve the enzyme active site (Levallet et al. 1998b). Testes of 20 bank voles (10 from 18L:6D, 10 from 6L:18D) 
were weighted and one testis per animal contributed to the two samples; one was used as the whole when the other was subjected to the enzymatic treatment. Remaining testes were used for steroid hormone analysis (see below). To obtain seminiferous tubules, samples were digested with collagenase-dispase $(0.05 \%)$, soybean trypsin inhibitor $(0.005 \%)$, and deoxyribonuclease $(0.001 \%)$ in Eagle's medium. Then, both, whole testes and seminiferous tubules were placed in buffer A [androstenedione (4 mM), DTT (dithiothreitol; $1 \mathrm{mM}$ ), sucrose $(0.25 \mathrm{M})$ ) (Sigma Chem. Co. St Louis, MO, USA), potassium phosphate buffer (50 mM, pH 7.4; Merck, Germany)]. Tissue was sonicated using Bandelin Sonopuls GM 70 apparatus. Then, a part of cell structures was removed by centrifugation in buffer $A$ at $20.000 \times g$ at $4^{\circ} \mathrm{C}$ for $30 \mathrm{~min}$. The supernatant was centrifuged in the above buffer for $1 \mathrm{~h}$ at $150.000 \times \mathrm{g}$, and next, the dispersed pellet was centrifuged for $1 \mathrm{~h}$ at $150.000 \times \mathrm{g}$ in buffer $\mathrm{B}$ [androstenedione $(4 \mathrm{mM})$; DTT (dithiothreitol, $1 \mathrm{mM})$; EDTA (0.2 M); glycerol (20\%)]. Finally, the microsomal pellet was suspended in a minimal volume of buffer $B$ and stored at $-20^{\circ} \mathrm{C}$ for further analysis, i.e. measurement of aromatase activity.

\section{Measurement of aromatase activity}

The activity of aromatase was assessed by measurement of ${ }^{3} \mathrm{H}_{2} \mathrm{O}$ released from $\left[1 \mathrm{~B}_{-}{ }^{3} \mathrm{H}\right]$ androst-4ene-3,17-dione (sp. act. $25.9 \mathrm{Ci} / \mathrm{nmol}$ ) as described previously (Thompson and Siiteri 1974). Incubations were performed in Tris-maleate buffer $(50 \mathrm{mM}, \mathrm{pH}$ 7.4) with tritiated androstenedione at $34^{\circ} \mathrm{C}$ for $1 \mathrm{~h}$. Reaction was initiated by the addition of NADPH $(10 \mathrm{mM}$ ) to a final volume of $0.5 \mathrm{~mL}$, and stopped by the addition of $1 \mathrm{ml}$ chloroform. After centrifugation $\left(2700 \times \mathrm{g}, 5 \mathrm{~min}, 4^{\circ} \mathrm{C}\right), 500 \mathrm{~mL}$ of the aqueous phase was removed, and steroids were extracted by incubation with $400 \mathrm{~mL}$ of activated-charcoal (7\%) suspension containing dextran (1.5\%) for 10 min at $4^{\circ} \mathrm{C}$. Then charcoal was separated from the aqueous phase by centrifugation $\left(2700 \times \mathrm{g}, 10 \mathrm{~min}, 4^{\circ} \mathrm{C}\right)$ and the radioactivity of the supernatant was measured in a liquid scintillation counter (Packard, Downers Grove, IL, USA). The ${ }^{3} \mathrm{H}_{2} \mathrm{O}$ assay for $\mathrm{P} 450$ aromatase activity was validated using increasing concentrations of both microsomal preparations. Control was included to verify that no tritiated water is released in the absence of NADPH-generating system. For positive and negative controls the microsomal frac- tions from human placenta and rat muscle were used, respectively. Protein concentration in microsomal preparations was evaluated according to the Bradford assay (Bradford 1976) using Bradford protein reagent (Bio-Rad Protein Assay) with bovine serum albumin (BSA) as a standard. The aromatase activity was expressed in $\mathrm{fmol}^{3} \mathrm{H}_{2} \mathrm{O}$ released per mg of protein per hour.

\section{Western blot analysis}

The microsomal fractions of whole testes or isolated seminiferous tubules served as a source of protein for immunoblot analysis. Samples ( $40 \mu \mathrm{g}$ protein each) were run on discontinuous polyacrylamide gels (5\% stacking and $12 \%$ separating gel) under denaturing conditions. After electrophoresis, the separated proteins were electrophoretically transferred to nitrocellulose membranes at $90 \mathrm{~mA}$, overnight at $4^{\circ} \mathrm{C}$. Then, they were washed again overnight with Tris-buffered saline (TBS; $0.05 \mathrm{M}$ Tris- $\mathrm{HCl}$ plus $0.15 \mathrm{M} \mathrm{NaCl}, \mathrm{pH} 7.6$ ) containing $5 \%$ fat free milk. Afterwards, the membranes were incubated in the presence of a rabbit polyclonal antibody against placental aromatase (the same as for immunohistochemistry) diluted to $1: 1000$ in TBS. Next, the membranes were rinsed to remove unbound antibody and incubated with a goat anti-rabbit IgG (1:600; Vector Lab., Burlingame, CA, USA) coupled to horseradish peroxidase (1:1000) for $1.5 \mathrm{~h}$ at room temperature. Bands were visualized by incubation in TBS containing DAB $(0.5 \mathrm{mg} / \mathrm{mL})$, and $0.3 \% \mathrm{H}_{2} \mathrm{O}_{2}$.

As a standard, Kaleidoscope Standard proteins (Bio-Rad Lab., Richmond, CA, USA) were used: miosin - $20.2 \mathrm{kDa} ; \beta$-galactosidase - $13.3 \mathrm{kDa}$; BSA - $71 \mathrm{kDa}$; carbonic anhydrase - $41.8 \mathrm{kDa}$; soybean trypsin inhibitor - 30.6 kDa; lysozyme - 17.8 kDa; aprotinin - 6.9 kDa.

\section{Steroid hormone analysis}

The homogenized testicular tissue was analyzed for androgen and estrogen contents using appropriate radioimmunoassays. Androgen concentrations were determined according to Dufau et al. (1972) using $\left[1,2,6,7,-{ }^{3} \mathrm{H}\right]$-testosterone (The Radiochemical Centre, Amersham, Buckinghamshire, UK), sp. act. $81.0 \mathrm{Ci} / \mathrm{mmol}$, as a tracer and an antibody raised in a rabbit against testosterone-3-0-carboxymethylooxime-bovine serum albumin (a gift from Professor Brian Cook, University of Glasgow, Scotland). Crossreactions for eight steroids were below $0.01 \%$, but cross-reactivity of $5 \alpha$-androstane-17 $\beta$-01-3-one 

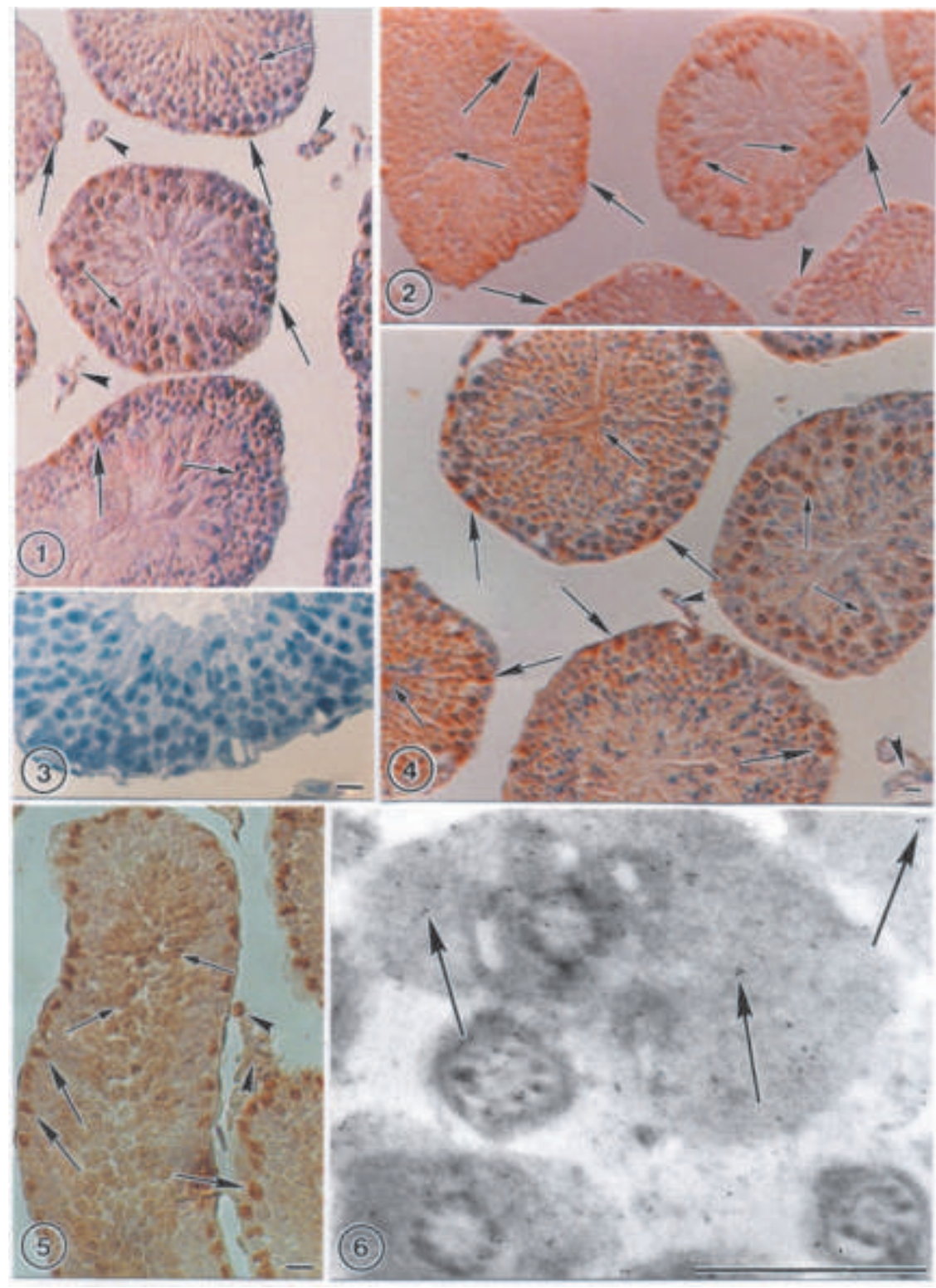

Figure 1. Section of a bank vole testis (6L:18D) immunostained for aromatase using R-10-2 antibody. Weak immunoreactivity for aromatase visible in Leydig cells (arrowheads), and germ cells (small arrows), strong immunoreactivity in Sertoli cells (larger arrows), Immunoreactions visualized with diaminobenzidine and counterstained with Mayer's haematoxylin. Scale bar represents $10 \mathrm{um}$. Figure 2. Section of a bank vole testis (6L:18D). Not counterstained. Intensity of immunoreactivities for aromatase the same as in Figure 1. Scale bar represents $10 \mu \mathrm{m}$. Figure 3 . Testis section incubated with normal rabbit serum instead of the primary antibody, counterstained with Mayer's haematoxylin. No immunoreactivity in all testicular cells. Scale bar represents $10 \mu \mathrm{m}$. Figure 4. Section of a bank vole testis (18L:6D) immunostained for aromatase and counterstained with Mayer's haematoxylin. Strong immunoreactivity for aromatase present in Sertoli cells as well as in germ cells at various stages (arrows). This differs from testis sections deriving from males kept in a short day. Scale bar represents $10 \mu \mathrm{m}$. Figure 5. A higher magnification from the testis section of a bank vole (18L:6D). Not counterstained. Strong immunoreactivity for aromatase in Sertoli cells is seen (larger arrows). Smaller arrows point to germ cells whereas arrowheads point to Leydig cells. Scale bar represents 10 um. Figure 6. Section of a bank vole testis (18L:6D). Immunohistochemistry at the electron-microscopy level. Gold particles over the cytoplasm of elongated spermatids are visible (arrows). Scale bar represents $1 \mu \mathrm{m}$. showed $100 \%$, dihydrotestosterone, $20.8 \%$, androstendione $15.7 \%$, androsterone $7.4 \%$ and dehydroepiandrosterone $3 \%$. The lower limit of sensitivity of the assay was of the order of 5 pg/tube. Coefficients of variation within and between assays were $7.5 \%$ and $9.7 \%$, respectively.

Estrogens were assessed according to Hotchkiss et al. (1971) using $\left[2,4,6,7,-{ }^{3} \mathrm{H}\right]$-oestradiol (The Radiochemical Centre, Amersham, Buckinghamshire, UK), sp. act. $86.0 \mathrm{Ci} / \mathrm{mmol}$, as a tracer and antibody raised in a rabbit against estradiol-17 $\beta$-6-oximeBSA (a gift from Professor Brian Cook, University of Glasgow, Scotland). The specificity of the antiserum for estrogen was high. It cross-reacted with estradiol
(100\%), with estrone (66\%), and with estriol (only $2.1 \%$ ). Other steroids were tested for cross-reactivity but they showed less than $0.1 \%$. The lower limit of sensitivity of the assay was of the order of $5 \mathrm{pg} / \mathrm{tube}$. Coefficients of variation within and between assays were $3.5 \%$ and $7.5 \%$, respectively.

\section{Statistical analysis}

Statistical evaluation of the data concerning aromatase activity included one-way analysis of variance (with the significance at $p<0.05$ ) and the Duncan's multiple range test, while to the data concerning steroid hormone concentrations the Student$\mathrm{T}$ test was used (the significance at $p<0.001$ ). 


\section{Results \\ Immunohistochemistry}

Aromatase visualized by means of immunohistochemistry was present in Leydig cells, and inside seminiferous tubules; in Sertoli cells, as well as in spermatocytes and spermatids (Figures $1,2,4,5$ ). In males that were kept in short light cycles positive immunoreaction for aromatase was weak except for Sertoli cells while in voles reared in long light cycles strong immunoreaction for the enzyme was observed. Intensity of immunostaining in testicular cells was always dependent on the length of photoperiod being stronger in animals reared in a long day than in those kept in a short one (Figures 4, 5 versus Figures 1,2 ). Irrespective of the photoperiod peritubular cells were negative for aromatase. In testicular sections in which the P450 aromatase antibody was omitted or replaced by normal rabbit serum there was no positive staining for aromatase (Figure 3).

At the ultrastructural level the gold particles were distributed over the cytoplasm of elongated spermatids captured just before their release into the lumen of the seminiferous tubule (Figure 6). This was found in the testes derived from voles that were kept in a long photoperiod. Nanogold particles were not visible over the cytoplasm in the tissue from males kept in a short day (not shown).

\section{Measurement of aromatase activity}

To confirm the immunolocalization of aromatase in testicular cells, the activity of this enzyme was measured in microsomal preparations from whole testes and seminiferous tubules. After validation of the ${ }^{3} \mathrm{H}_{2} \mathrm{O}$ assay for $\mathrm{P} 450$ aromatase activity a linear relationship has been observed between the amount of tritiated water released and the quantity of protein incubated. The aromatase activity was detected in microsomal fractions from both the whole testes and seminiferous tubules of the bank voles that were kept either in long light cycles or in short ones. In the whole testes from a long day voles the activity of aromatase was $222.66 \pm 13.85 \mathrm{fmoles} / \mathrm{mg}$ protein/h while from the short day males it was about $135.65 \pm 4.05 \mathrm{fmoles} / \mathrm{mg}$ protein/h. Statistical significance was found at the level $p<0.05$.

In the seminiferous tubules aromatase activity was $100.23 \pm 4.56$ and $47.19 \pm 1.84 \mathrm{fmoles} / \mathrm{mg}$ protein $/ \mathrm{h}$, in bank voles from a long or short photoperiod, respectively (Figure 7 ). This difference was statistically significant $(p<0.05)$.

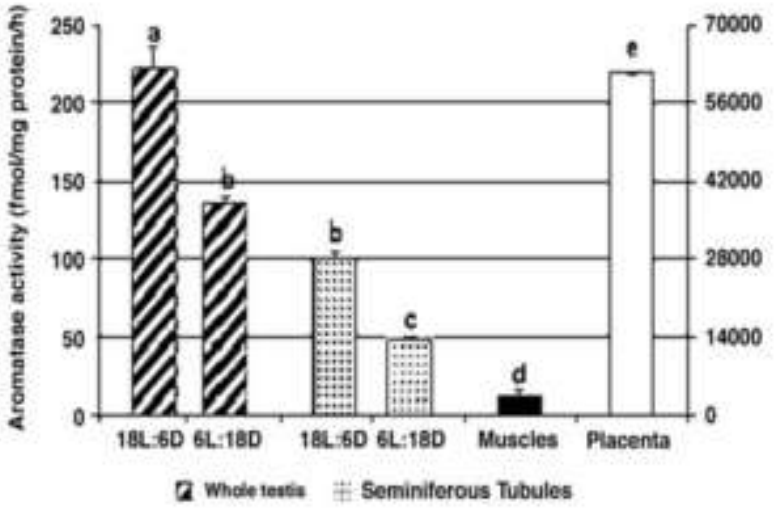

Figure 7. P450 aromatase activity in microsomal fractions of the whole testis (stripped bars) and of seminiferous tubules (dotted bars).18L: 6D = long photoperiod, 6L:18D = short photoperiod. Rat muscle and human placenta used as controls. The right scale is only for the placenta. Values are means \pm SEM $(n=3)$; means without common superscripts $(a, b, c)$ are statistically different $(p<0.05)$.

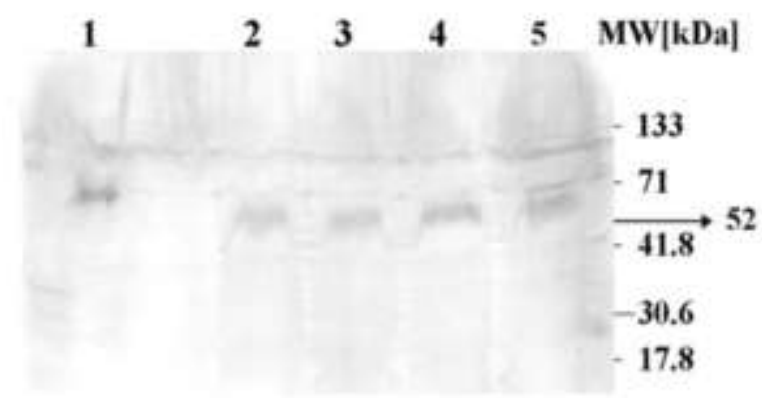

Figure 8. Western blot of aromatase in microsomal fractions of the whole testis (6L:18D - lane 2; 18L: 6D - lane 4) and of seminiferous tubules (6L:18D - lane 3 and 18L: 6D - lane 5). Lane 1positive control, rat ovarian granulosa cells. MW in kilodaltons (kDa).

\section{Western blot}

Expression of cytochrome P450 aromatase was examined by Western immunoblotting analysis. Immunodetectable protein as bands of about 52 $\mathrm{kDa}$, were observed in microsomal preparations from whole testis and seminiferous tubules (Figure 8). The intensity of immunoblot was slightly higher in the microsomal fraction from voles kept in long light cycles than from those reared in short ones. A band of about $56 \mathrm{kDa}$ obtained from rat ovarian granulosa cells served as a positive control.

\section{Radioimmunological analysis}

Radioimmunological analysis of steroid hormone levels revealed that testosterone concentration in 


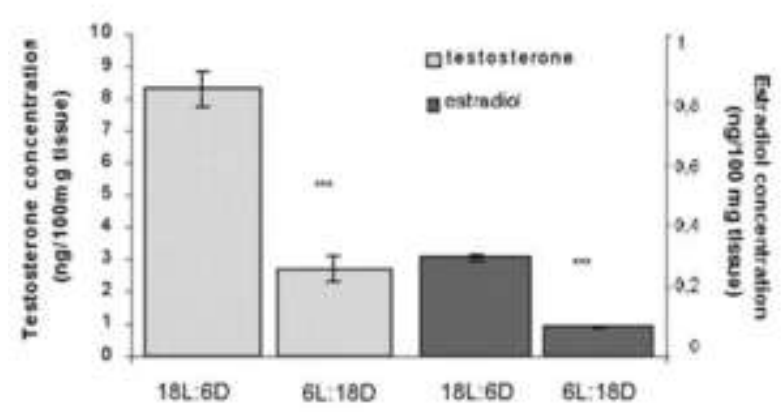

Figure 9. Testosterone and estrogen levels in homogenized testicular tissue of the bank voles. 18L: 6D = long photoperiod, 6L:18D $=$ short photoperiod. Means $\pm \operatorname{SEM}(n=6)$; $* * * p<0.001$.

homogenates of testes from males kept in a long day was 3-fold higher than that of males reared in a short day ( $18 \mathrm{~L}: 6 \mathrm{D}$ versus $6 \mathrm{~L}: 18 \mathrm{D}=8.31 \pm 0.55 \mathrm{ng}$ versus $2.7 \pm 0.38 \mathrm{ng} / 100 \mathrm{mg}$ tissue, Figure 9). The difference was statistically significant at $p<0.001$.

In comparison with testosterone, estradiol level was relatively low, however also 3-fold higher in males from a long day than in those from a short day (18L:6D versus $6 \mathrm{~L}: 18 \mathrm{D}=270.2 \pm 8.2 \mathrm{pg}$ versus $80.3 \pm 4.5 \mathrm{pg} / 100 \mathrm{mg}$ tissue, respectively, Figure 9). Statistical significance was found at the level $p<0.001$.

\section{Discussion}

In several papers dealing with the bank vole reproduction (Clarke 1985; Tähkä et al. 1997; Bilinska et al. 1999), differences in the steroidogenic activity and testosterone secretion by Leydig cells derived from males reared in long or short light cycles have been described. According to these authors, bank voles express seasonal, dependent on light regime, testicular activity which, if pronounced enough, is associated with increased/decreased development of cell organelles, responsible for steroidogenic function of the testis, and, in consequence in higher/lower steroid hormone production. Close dependence between the distribution of androgen receptors, age of the animals, and light regimes was recently reported by Tähkä et al. (1997) and Bilinska et al. (1999).

Based on the recent literature (for review, see Sharpe, 1998; Carreau et al., 1999; Hess, 2000; Hess et al., 2001) postulating the role of estrogens in the male genital tract, an attempt was made to show the cellular site of aromatization in the bank vole testis by means of several complementary techniques.

In testicular sections of bank voles, the immunoreactivity for aromatase was found in Leydig cells, Sertoli cells, and germ cells, mainly in spermatocytes and spermatids. The technique with colloidal gold has allowed us to demonstrate for the first time the aromatase in the cytoplasm of elongated spermatids. Concomitantly, in testicular homogenates high quantities of testosterone and estradiol were measured, indicating that in the bank vole testis aromatase is present, and converts androgens to estrogens. Moreover, Western blot analysis revealed the presence of the protein about $52 \mathrm{kDa}$ in size (not $55 \mathrm{kDa}$ as previously described in the rat) within microsomal preparations of the whole testes or isolated seminiferous tubules. The above data correlate well with the further step of this study showing the activity of functional P450 aromatase as confirmed by the measurement of tritiated water release after incubation of microsomal preparations obtained from the whole testes or isolated seminiferous tubules with labeled androstendione. These findings confirm the results of previous studies on cytochrome $\mathrm{P} 450$ aromatase (Levallet and Carreau 1997; Levallet et al. 1998a) showing the presence of functional enzyme in rat testicular cells. Aromatase expression in purified adult rat germ cells was there examined based on Western blot analysis, measurement of enzyme activity, and detection of P450arom mRNA. In a consecutive study of our own the immunoreactive aromatase was localized within the seminiferous tubules (Levallet et al. 1998b). Immunostaining was positive not only in spermatocytes and round spermatids but also in more mature germ cells within the tubule lumen, most likely spermatozoa which exhibited the immunoreactivity both in their heads and along flagella. Thus, well documented evidence was provided for the presence of P450 aromatase in the adluminal compartment of the rat testis, as previously reported in the mouse, bear, and rooster (Nitta et al. 1993; Tsubota et al. 1993; Kwon et al. 1995). Using a highly specific quantitative RT-PCR method Levallet et al. (1998b) revealed P450arom mRNA in Sertoli cells, Leydig cells, and germ cells which is consistent with the report of Janulis et al. (1998).

In the rat and mouse aromatase immunoreactivity has also been found in spermatozoa residing in the epidydimis. It decreased along the epididymal tract from its caput to the cauda (Janssen et al., 1994; 
Janulis et al. 1996). The high concentration of estradiol in rat rete testis fluid (Free and Jaffe, 1979) and the presence of estrogen receptors in the epididymis are likely to be related to the important role for estrogens in the male genital tract. After castration, the androgens alone are unable to restore the structure of the head of the epididymis (Fawcett and Hoffer, 1979) and non-androgen sperm associated factors are required (Douglas et al. 1991). Therefore, it is possible that estrogens produced by the spermatozoa may play this role in the proximal part of the rodent epididymis.

Recently, age-dependent distribution of aromatase in rat testes was observed by Carpino et al. (2001). During postnatal development they showed an increase or decrease in aromatase expression by Leydig cells or Sertoli cells, respectively. According to the data of Tsai-Morris et al. (1985) and Papadopoulos et al. (1986) the aromatase is present both in Leydig and Sertoli cells during rat testis development. At the same time, however, Kurosumi et al. (1985) showed that immunoreactive aromatase was restricted to Leydig cells only. Also, in equine or ovine testes, only Leydig cells were found as a site of aromatase (Almahdidi et al. 1995; Bilinska et al. 1997). Our latest data indicate that in young voles, Leydig and Sertoli cells express the immunoreactive aromatase (Bilinska et al. 2001). In young voles kept in a short day there was no positive staining in germ cells, whereas keeping the animals under long light cycles induced immunoreactivity in spermatogonia and spermatocytes. This is consistent with findings described by Carpino et al. (1999) indicating that germ cells from juvenile rat testes express immunoreactivity for aromatase.

In the present study it was found that in germ cells from adults kept in a long day, immunostaining for aromatase was stronger, band of the protein in the immunoblot was more distinct as well as the activity of the enzyme was higher in animals reared in short day conditions. It should be summarized therefore, that the presence of functional aromatase is clearly dependent on the length of light/dark cycles.

Thus, the widespread distribution of aromatase in testicular cells of the bank vole seems to be consistent with the proposed role for estrogens in regulation of spermatogenesis (Hess et al. 1997 a,b; Hess, 2000; Lee et al. 2000; for review, see Carreau et al.1999; 0'Donnell et al. 2001; Hess et al. 2001). According to Hess and co-workers a high concentration of estrogen in rete testis fluids, the widespread distribution of estrogen receptors in the male reproductive tract, and the stimulation of fluid reabsorption in the efferent ductules (nearly $90 \%$ of the luminal fluids) indicate the important physiological function of estrogen in the males. The evidence collected from estrogen receptor- $\alpha$ knockout mouse model strongly supported the above hypothesis (Hess et al. 1997a, Hess, 2000; for review, see Hess et al. 2001). Lack of P450 aromatase expression in aromatase knockout mice (ArKO) is associated with testicular degeneration (Carani et al. 1997; Robertson et al. 1999) and poor libido (Honda et al. 1998). Indeed, Robertson et al. (1999) and very recently, 0'Donnell et al. (2001) have shown that in ArKO male mice reduced fertility follows impairment of spermatogenesis at the round spermatid stage.

Estrogens produced by germ cells may also be involved in paracrine regulation of Sertoli cell function (Boitani et al. 1981), and vice versa, since we observed a strong immunoreactivity for aromatase in Sertoli cells. Therefore, it is possible that the capacity of testicular cells to aromatize androgens into estrogens is important for complex interactions between the interstitial area and the tubular compartment.

Taking into account data presented herein, the important and species-dependent role for estrogens in the regulation of testicular function is suggested. It is worth mentioning that strong immunoreaction for aromatase in Sertoli cells of adult bank voles indicates differences among various rodent species in this respect. On the basis of results obtained using several complementary techniques applied in this study, germ cells and Sertoli cells should be considered as a new source of estrogens in adult bank vole testis.

\section{Acknowledgements}

This work was partly supported by the Polonium grant C14/00 (01420PJ) and in part by the PBZ$K B N-084 / P 06 / 2002$ fund from the State Committee for Scientific Research, as well as the SMA grant of the World Health Organization, Special Programme of Research, Development and Research Training in Human Reproduction.

The authors are indebted to Dr. Danuta Semik and Ada Jankowska MSc for their help with the EM technique, and to Mr. Jaroslaw Kadulski for tending the bank vole colony. 


\section{References}

Almahdidi I, Seralini GE, Fresnel J, Silberzahn P, Gaillard JL. Immunohistochemical localization of cytochrome P450 aromatase in equine gonads. J Histochem Cytochem 1995;43:571-7.

Bilinska B, Lesniak M, Schmalz B. Are ovine Leydig cells able to aromatize androgens? Reprod Fertil Dev 1997;9:193-9.

Bilinska B, Drag E, Schmalz-Fraczek B. Immunolocalization of androgen receptors in testicular cells during postnatal development of the bank vole (Clethrionomys glareolus, S.). Tissue Cell 1999;31:621-6.

Bilinska B, Schmalz-Fraczek B, Kotula M, Carreau S. Photoperioddependent capability of androgen aromatization and the role of estrogens in the bank vole testis visualized by means of immunohistochemistry. Mol Cell Endocrinol 2001;178: 189-98.

Boitani C, Ritzen EM, Parvinen M. Inhibition of rat Sertoli cell aromatase by factor(s) secreted specifically at spermatogenic stages VII and VIII. Mol Cell Endocrinol 1981;23:11-22.

Bradford MM. A rapid and sensitive method for the quantitation of microgram quantities of protein utilizing the principle of protein-dye binding. Anal Biochem 1976;72:248-54.

Brodie A, Inkster S, Yue W. Aromatase expression in the human male. Mol Cell Endocrinol 2001;178:23-8.

Carani C, Qin K, Simoni M, Faustini-Faustini M, Serpent S, Boyd J, et al. Effect of testosterone and estradiol in a man with aromatase deficiency. N Engl J Med 1997;337:91-5.

Carpino A, Bilinska B, Pezzi V, Rago V, Ando S. Immunohistochemical localization of P450 aromatase in cultured Sertoli cells and testis sections from immature Wistar rats. Mol Cell Endocrinol 1999; 155:193[abstract].

Carpino A, Pezzi V, Rago V, Bilinska B, Ando S. Immunolocalization of cytochrome P450 aromatase in rat testis during postnatal development. Tissue Cell 2001;33:349-53.

Carreau S, Genissel C. Bilinska B, Levallet J. Sources of oestrogen in the testis and reproductive tract of the male. Int $J$ Androl 1999;22:21123.

Clarke JR. The reproductive biology of the bank vole and the wood mouse. Symp Zool Soc London 1985;55:33-59.

Conley A, Hinshelwood M. Mammalian aromatases. Reproduction 2001; 121:685-95.

Conley AJ, Corbin CJ, Hinshelwood MM, Liu Z, Simpson ER, Ford JJ, et al. Functional aromatase expression in porcine adrenal gland and testes. Biol Reprod 54 1996;497-505.

Douglass J, Garrett SH, Garrett KE. Differential patterns of regulated gene expression in the adult rat epididymis. In: Robaire $B$, ed. The Male Germ Cell. Ann NY Acad Sci 1991;637:384-98.

Dufau ML, Catt KJ, Tsuruhara T, Ryan D. Radioimunoassay of plasma testosterone. Clin Chim Acta 1972;37:109-16.

Fawcett DW, Hoffer AP. Failure of exogenous androgen to prevent regression of initial segments of rat epididymis after efferent duct ligation or orchidectomy. Biol Reprod 1979;20:162-81.

Free PJ, Jaffe RA. Collection of rete testis fluid from rats without previous efferent duct ligation. Biol Reprod 1979;20:269-78.

Hess RA. Oestrogen in fluid transport and reabsorption in efferent ducts of the male reproductive tract. Rev Reprod 2000;5:84-92.

Hess RA, Bunick D, Lee KH, Bahr J, Taylor JA, Korach KS, et al. A role for oestrogen in the male reproductive tract. Nature 1997a;390:50912.

Hess RA, Gist DH, Bunick D, Lubahn DB, Farrell A, Bahr J, et al. Estrogen receptor ( $\alpha$ and $\beta$ ) expression in the excurrent ducts of the adult male rat reproductive tract. J Androl 1997b;18:602-11.

Hess RA, Bunick D, Lubahn DB, Zhou Q, Bouma J. Morphologic changes in efferent ductules and epididymis in estrogen receptor- $\alpha$ knockout mice. J Androl 2000;21:107-21.

Hess RA, Bunick D, Bahr J. Oestrogen, its receptors and function in the male reproductive tract - a review. Mol Cell Endocrinol 2001;178: 29-38.

Honda S, Harada N, Ito S, Takagi Y, Maeda S. Disruption of sexual behavior in male aromatase-deficient mice lacking exons 1 and 2 of the cyp 19 gene. Biochem Biophys Res Commun 1998;252:445-9.

Hotchkiss J, Atkinson LE, Knobil E. Time course of serum estrogen and luteinizing hormone concentrations during menstrual cycle of rhesus monkey. Endocrinology 1971;89:;177-83.

Jakob F, Homann D, Seufert J, Schneider D, Kohrle J. Expression and regulation of aromatase cytochrome $\mathrm{P} 450$ in THP 1 human myeloid leukaemia cells. Mol Cell Endocrinol 1995;11:27-33.

Janssen S, Janulis L, Bahr JM, Bunick D, Osawa Y, Hess RA. P450 aromatase in the rat testis and epididymis. J Androl 1994;15Suppl 1:212.

Janulis $S L$, Hess RA, Bunick D, Nitta $H$, Janssen $S$, Osawa $Y$, et al. Mouse epididymal sperm contains active P450 aromatase which decreases as sperm traverse the epididymis. J Androl 1996;17:1116.

Janulis L, Bahr JM, Hess RA, Janssen S, Osawa Y, Bunick D. Rat testicular germ cells and epididymal sperm contain active P450 aromatase. J Androl 1998;19:65-71.

Kurosumi M, Ishimura K, Fujita $\mathrm{H}$, Osawa, Y. Immunocytochemical localization of aromatase in rat testis. Histochemistry 1985;83:401-

Kwon S, Hess RA, Bunick D, Kirby JD, Bahr JM. Rooster testicular germ cells and epididymal sperm contain P450 aromatase. Biol Reprod 1995;53:1259-64.

Lee KH, Hess RA, Bahr JM, Lubahn DB, Taylor J, Bunick D. Estrogen receptor $\alpha$ has a functional role in the mouse rete testis and efferent ductules. Biol Reprod 2000;63:1873-80.

Levallet J, Carreau S. Aromatase gene expression in rat testicular cells in vitro. C R Acad Sci Paris 1997;320:123-9.

Levallet J, Mittre $H$, Delarue $B$, Carreau S. Alternative splicing in the coding region of the cytochrome $\mathrm{P} 450$ aromatase gene in male germ cells. J Mol Endocrinol 1998a;20:305-12.

Levallet J, Bilinska B, Mittre H, Fresnel J, Carreau S. Expression and immunolocalization of functional cytochrome P450 aromatase in mature rat testicular cells. Biol Reprod 1998b;58: 919-26.

Nitta H, Bunick D, Hess RA, Janulis L, Newton SC, Millette CF, et al. Germ cells of the mouse testis express P450 aromatase. Endocrinology 1993;132:1396-401.

Noble LS, Simpson ER, Johns A, Bulun SE. Aromatase expression in endometriosis. J Clin Endocrinol Metab 1993;81:174-9.

0'Donnell L., Robertson KM, Jones ME, Simpson ER. Estrogen and spermatogenesis. Endocr Rev 2001;22:289-318.

Papadopoulos V, Carreau S, Szerman-Joly E, Drosdowsky MA, Dehennin L, Scholler R. Rat testis $17 \beta$-oestradiol: identification by gas chromatography-mass spectrometry and age related cellular distribution. J Steroid Biochem 1986;24/1211-26.

Robertson KM, O'Donnell L, Jones ME, Meachem SJ, Boon WC, Fisher $\mathrm{CR}$, et al. Impairment of spermatogenesis in mice lacking a functional aromatase (cyp 19) gene. Proc Natl Acad Sci USA 1999;96: 7986-91.

Santner SJ, Pauley R, Tait L, Kaseta J, Santen R. Aromatase activity and expression in breast cancer and benign breast tissue stromal cells. $\mathrm{J}$ Clin Endocrinol Metab 1997;82:200-8.

Sharpe RM. The roles of oestrogen in the male. Trends Endocrinol Metab 1998;9:371-7.

Simpson ER, Mahendroa MS, Means GD, Kilgore MW, Hinshelwood MM, Graham-Lorence S, et al. Aromatase cytochrome P450, the enzyme responsible for oestrogen biosynthesis. Endocr Rev 1994;15: 342-55.

Tähkä KM, Teräväinen T, Wallgren H. Effect of photoperiod on the testicular steroidogenesis of the bank vole (Clethrionomys glareolus, Schreber): an in vitro study. Gen Comp Endocr 1982;47:377-84.

Tähkä KM, Zhuang YH, Tähkä S, Tuohimaa P. Photoperiod induced changes in androgen receptor expression in testes and accessory sex glands of the bank vole Clethrionomys glareolus. Biol Reprod 1997; 56:898-908.

Thompson EA Jr, Siiteri PK. Utilization of oxygen and reduced nicotinamide adenine dinucleotide phosphate by human placental microsomes during aromatization of androstenedione. J Biol Chem 1974; 249:5364-72.

Tsai-Morris C, Aquiano DR, Dufau ML. Cellular localization of rat testicular aromatase activity during development. Endocrinology 1985; 116:38-46

Tsubota T, Nitta H, Osawa $Y$, Mason IJ, Kita I, Tiba T, et al. Immunolocalization of steroidogenic enzymes, P450scc, 3 $\beta$-HSD, P450c17, and P450arom in the Hokkaido brown bear (Ursus arctos yesoensis) testis. Gen Comp Endocr 1993;92:439-44.

Yosida N, Osawa Y. Purification of human placental aromatase cytochrome P-450 with monoclonal antibody and its characterization. Biochemistry 1991;30:3003-10. 